\title{
The Chesapeake Bay Impact Structure
}

\section{An Ancient Catastrophe}

About 35 million years ago, during late Eocene time, a 2-mile-wide asteroid or comet smashed into Earth in what is now the lower Chesapeake Bay in Virginia (location map). The oceanic impact vaporized, melted, fractured, and (or) displaced the target rocks and sediments and sent billions of tons of water, sediments, and rocks into the air. Glassy particles of solidified melt rock rained down as far away as Texas and the Caribbean. Models suggest that even up to 50 miles away the velocity of the intensely hot air blast was greater than 1,500 miles per hour, and ground shaking was equivalent to an earthquake greater than magnitude 8.0 on the Richter scale. Large tsunamis affected most of the North Atlantic basin. The Chesapeake Bay impact structure is among the 20 largest known impact structures on Earth.

\section{Discovering the Impact Structure}

Hydrologists from the U.S. Geological Survey (USGS) noticed the unusual presence of salty groundwater in the southern Chesapeake Bay area in the 1940s and 1950s. In the mid-1980s, a chaotic mixture of sediments and fossils that varied in age from 135 to 35 million years was recovered from several coreholes drilled in the region. Shocked quartz, a structurally altered type of quartz that forms naturally only during meteorite impact events, was found in this chaotic mixture (impact breccia) in the early 1990s. Additional drilling showed that the distribution of these sediments matched the distribution of the salty groundwater.

Seismic surveys (acoustic images of subsurface materials) released by the petroleum industry in the early 1990s revealed the shape, internal configuration, and boundaries of the structure. By the late 1990s, the existence of the buried impact structure, its general form, and its effects on regional groundwater resources were well established.

\section{Deep Drilling into the Impact Structure}

Since 2000, the USGS and its partners have drilled deep coreholes in the impact structure at six sites. Samples from those holes were analyzed to discover more about the structure's size, composition, age, and biological effects, and to better understand its lingering influences on the regional groundwater system.

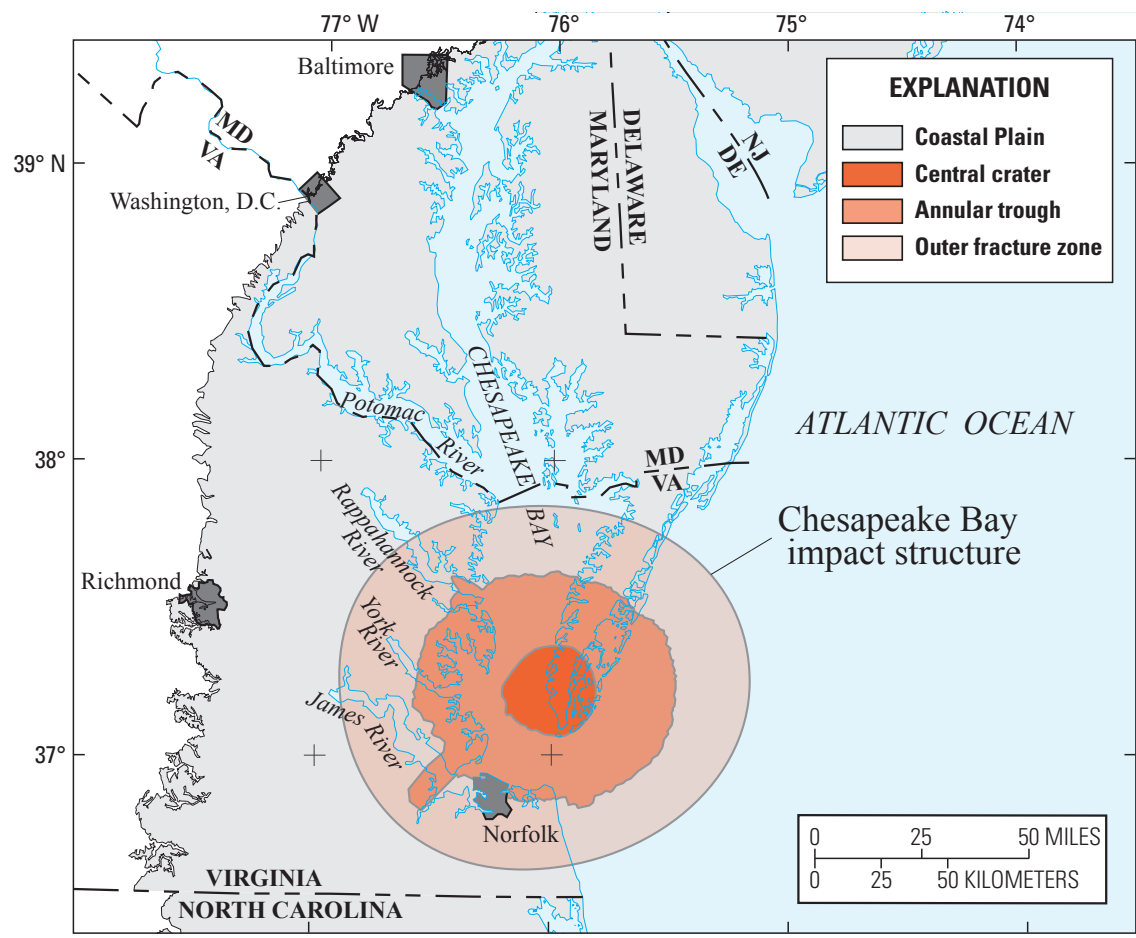

Location map of eastern Virginia and the Delmarva Peninsula showing the extent of the Chesapeake Bay impact structure.

\section{How big is the Chesapeake Bay impact structure?}

The Chesapeake Bay impact structure now lies buried beneath hundreds of feet of sediments of the Virginia Coastal Plain (location map). All estimates of its size and shape are based on information derived from drilling and geophysical surveys.

The geology of the impact target area consisted of three layers: an upper layer of seawater; a middle layer of sediments; and a lower layer of igneous and metamorphic rocks, called basement rocks. The impact structure also consists of three parts: (1) a central crater, which, upon impact, briefly existed as a hole (transient crater) that was about 16 miles wide and 5 miles deep before its walls collapsed and its floor rebounded (central uplift), partly filling the hole in a few minutes; (2) an annular trough, in which widespread impact deformation primarily was limited to the sediment and uppermost basement layers; and (3) an outer fracture zone, where isolated faults and areas of disruption occur also in the same layers.

The collapsed central crater is about 23 miles in diameter. If the widths of the annular trough and outer fracture zone are included, the full diameter of the structure is about 83 miles. Published diameter values vary depending upon which parts of the structure are being considered.

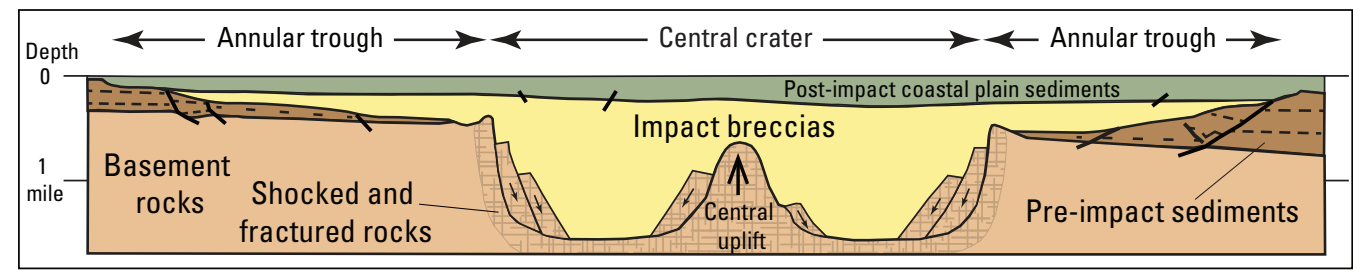

Schematic cross section of part of the impact structure. Note the central crater and the shallow annular trough. Water is not shown. Vertical exaggeration $\times 5$. 
Research efforts culminated in the drilling and analysis of a 1.1-mile-deep, continuously sampled corehole in the central crater by an international group of scientists and agencies in 2005 .

\section{Impact Effects in Southeastern Virginia Today}

Until the impact structure was discovered, there was no satisfactory explanation for the origin of groundwater that has salinities up to twice that of modern seawater in the area of the impact structure. This brine typically is not found in deep sediments west of the modern Atlantic coastline. A geochemically determined age of 140 to 100 million years for deep samples of this brine from the impact structure corresponds with the age of the deepest sediments disrupted by the impact. Therefore, ancient North Atlantic brine has remained in place at great depths in the impact structure to the present.

Higher in the impact structure, groundwater salinities remain high due to upward transport of the brine by diffusion and slow compaction of the impact materials, but decrease somewhat due to dilution by younger, less saline groundwater. A growing need for freshwater in the metropolitan area above the impact structure has led several municipalities to install brackish-water desalination plants.

Continued subsidence and sediment compaction within the structure has maintained a topographic low that has caused geologically recent and modern rivers to drain toward it, thereby controlling the location of the Chesapeake Bay to some extent.

Together, these observations point to the fact that this 35-million-year-old impact structure is still affecting us today.

\section{Frequently Asked Questions}

Did this event kill the dinosaurs? No. The impact associated with the extinction of the non-avian dinosaurs occurred on the Yucatán Peninsula of Mexico about 30 million years before the Chesapeake event.

Did this event kill anything? Yes. All life on land and in the sea for tens of miles from the impact point would have been destroyed. In combination with other impacts of similar age, its effects may have contributed to moderate levels of global extinction of land and sea life and the start of major global cooling at the end of the Eocene Epoch.

\section{USGS Partners in the study of the Chesapeake Bay impact structure:}

International Continental Scientific Drilling Program (ICDP); Virginia Department of Environmental Quality; Hampton Roads Planning District Commission; National Aeronautics and Space Administration (NASA) Langley Research Center; NASA Science Mission Directorate; and Drilling, Observation, and Sampling of the Earth's Continental Crust (DOSECC).

\section{By David S. Powars, Lucy E. Edwards, Gregory S. Gohn, and J. Wright Horton, Jr.}

Eastern Geology and Paleoclimate Science Center, U.S. Geological Survey,

926A National Center, 12201 Sunrise Valley Drive, Reston, VA 20192

Contact: dspowars@usgs.gov; http://geology.er.usgs.gov/egpsc

\section{For more information:}

\section{Research studies:}

http://pubs.usgs.gov/pp/p1612/

http://pubs.usgs.gov/pp/2005/1688/ak/

http://specialpapers.gsapubs.org/content/458

\section{Salty groundwater:}

http://www.usgs.gov/newsroom/article.asp?ID=3725

\section{Earth Impact Database:}

http://www.passc.net/EarthImpactDatabase/

\section{Create an impact:}

https://www.purdue.edu/impactearth

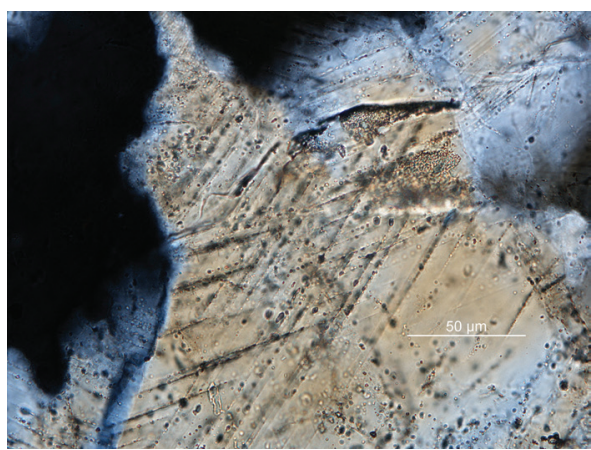

View of microscopic shocked-quartz grain. Note the crossing sets of parallel deformation features in the center of the photograph. Scale in micrometers.

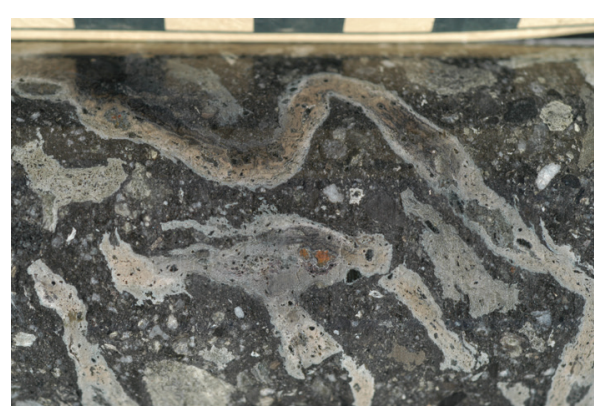

Clasts of glassy rock that quickly solidified from a mixture of impact-melted rocks. These crooked, light-colored clasts from the central crater are partly altered to clay. Scale in centimeters.
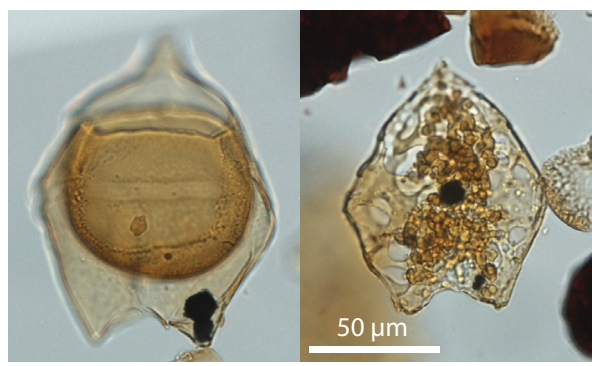

Normal microfossil specimen (dinocyst) (left) and partly melted specimen from the impact structure (right). Scale in micrometers.

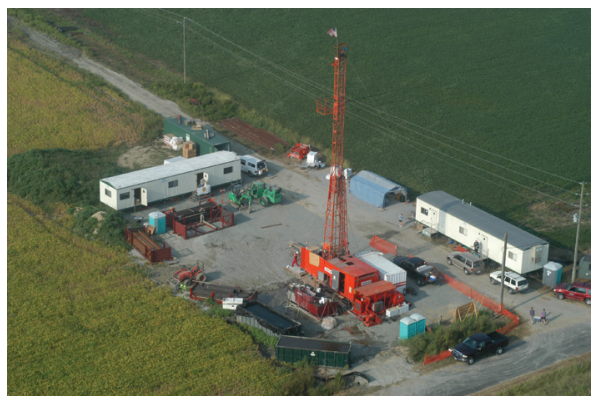

Eyreville drill site near Cheriton, Northampton County, Va., in 2005. The corehole drilled at this site reached a depth of 1.1 miles in the central crater. 